\title{
Effects of the inclusion of glycerin in diets containing 30 or $70 \%$ roughage on feed disappearance and digestibility
}

\section{Efeito da inclusão de glicerina em dietas contendo 30 ou $70 \%$ de forragem sobre o desaparecimento e a digestibilidade de alimentos}

\author{
Antonio Carlos Homem Junior ${ }^{1 *}$; Jane Maria Bertocco Ezequiel²; Leonardo \\ Fernandes Cremasco ${ }^{3}$; Marco Túlio Costa Almeida ${ }^{4}$; Josimari Regina Paschoaloto ${ }^{1}$; \\ André Pastori D’Áurea ${ }^{1}$; Henrique Leal Pérez ${ }^{5}$
}

\begin{abstract}
The objective of this study was to evaluate in vitro nutrient disappearance and in vivo nutrient digestibility of cattle diets containing 70 or $30 \%$ roughage, with and without glycerin supplementation. Four Nellore cattle were used in the study based on a $4 \times 4$ Latin Square design in a $2 \times 2$ factorial arrangement. Inclusion of glycerin and roughage proportion did not affect the nutrient disappearance of each ingredient $(\mathrm{P}>0.05)$. Regardless of the inclusion of glycerin, a reduction in the proportion of roughage led to an increase $(\mathrm{P}<0.05)$ in DMDis $(64 v s .72 \%)$, NDFDis $(41 v s .54 \%)$, and ADFDis (31 vs. $44 \%)$ of the total rations. Inclusion of glycerin resulted in an increase $(\mathrm{P}<0.05)$ in DMD $(70 v s$. $62 \%)$ and a reduction $(\mathrm{P}<0.05)$ in CPD $(32 v s .38 \%)$ and STD $(82 v s .74 \%)$. The diet containing $30 \%$ roughage led to higher $(\mathrm{P}<0.05)$ DMD $(67 v s .65 \%)$ and CPD $(35$ vs. 33\%) in comparison with the $70 \%$ roughage diet, but did not differ $(\mathrm{P}>0.05)$ in STD $(78 \%)$. Inclusion of glycerin at $20 \%$ of the total DM increased the utilisation of dietary DM without affecting the fibrous fraction of the diet. Glycerin supplementation in diets containing $70 \%$ roughage improves neutral detergent fibre digestibility.
\end{abstract}

Key words: INDF. Glycerol. Ingredients. In vitro. In vivo. Total ration.

\section{Resumo}

O objetivo deste estudo foi avaliar o desaparecimento in vitro de nutrientes e a digestibilidade in vivo de alimentos para bovinos contendo 70 ou $30 \%$ de forragem, com e sem suplementação de glicerina. Foram utilizados quatro bovinos Nelore num delineamento quadrado latino $4 \times 4 \mathrm{em}$ um esquema fatorial $2 \times$ 2. A inclusão de glicerina e forragem não afetou o desaparecimento de nutrientes dos ingredientes $(\mathrm{P}>$ $0,05)$. Independentemente da inclusão de glicerina, uma redução na proporção de forragem provocou um aumento $(\mathrm{P}<0,05)$ na DesMS (64 vs. $72 \%)$, DesFDN (41 versus 54\%) e DesFDA (31 vs. 44\%) das rações totais. A inclusão de glicerina resultou em um aumento $(\mathrm{P}<0,05)$ na DMS $(70$ contra $62 \%)$ e uma redução $(\mathrm{P}<0,05)$ na DPB (32 vs. 38\%) e DAM (82 versus $74 \%)$. A dieta contendo $30 \%$ de forragem proporcionou maior $(\mathrm{P}<0,05)$ DMS $(67$ vs. $65 \%)$ e DPB (35 versus $33 \%)$ em comparação à

1 Drs. em Zootecnia, Universidade Estadual Paulista, FCAV, Jaboticabal, SP, Brasil. E-mail: achomemj@hotmail.com; jpaschoaloto@yahoo.com.br

2 Profa, FCAV, Jaboticabal, SP, Brasil. E-mail: janembe_fcav@yahoo.com.br

3 Zootecnista, FCAV, Jaboticabal, SP, Brasil. E-mail: leonardocremasco@yahoo.com.br

4 Discente, Curso de Doutorado do Programa de Pós-Graduação em Zootecnia, FCAV, Jaboticabal, SP, Brasil. E-mail: marco695@ yahoo.com.br

5 Prof., Universidade Estadual de Maringá, UEM, Maringá, PR, Brasil. E-mail: hlperez@hotmail.com

* Author for correspondence 
dieta com $70 \%$ de forragem, mas não diferiu (P > 0,05) na DAM (78\%). A inclusão de $20 \%$ de glicerina aumentou a utilização de MS sem afetar a da fração fibrosa da dieta. A suplementação de glicerina em dietas contendo $70 \%$ de forragem melhora a digestibilidade de fibra de detergente neutro.

Palavras-chave: FDNi. Glicerol. Ingredientes. In vitro. In vivo. Ração total.

\section{Introduction}

Currently, the use of low-roughage diets for feedlot beef cattle has increased. According to the literature, a reduction in the proportion of dietary roughage improves nutrient digestibility (VÉRAS et al., 2000; RESENDE et al., 2001; ÍTAVO et al., 2002; SILVA et al., 2005; PEREIRA et al., 2007). Many alternative ingredients are available on the market for formulating different animal feeds. Soybean hulls are a roughage ingredient and crude glycerin a concentrate; both are high-energy ingredients and are increasingly used in ruminant feed, minimising the use of corn grain.

Glycerin supplementation can bring benefits to rumen health, as it minimises the sharp drop in $\mathrm{pH}$ that frequently occurs when a high concentration of corn is used in diets. The inclusion of glycerol at a concentration higher than $5 \%$ of dietary dry matter (DM) may inhibit the in vitro growth of cellulolytic bacteria (ROGER et al., 1992), but studies reported that the inclusion of glycerol at $15 \%$ of dietary DM did not affect in vivo neutral detergent fibre digestibility (DONKIN, 2008; AVILA-STAGNO, 2013).
Some methods used for the evaluation of feed for ruminants, such as the total collection of faeces, involve greater operational difficulties when compared to in vitro or in vivo methods that use internal indicators. In vitro and in vivo methods that use indicators have the advantage of allowing separate analysis of the performance of total rations and ration ingredients.

The present study was conducted to evaluate the in vitro nutrient disappearance and in vivo nutrient digestibility of cattle diets containing 30 or $70 \%$ of roughage, with and without the inclusion of glycerin.

\section{Material and Methods}

Four ruminally cannulated Nellore cattle, weighing approximately $450 \mathrm{~kg}$ each and housed individually in $12 \mathrm{~m}^{2}$ semi-covered stalls, were used in this study. The animals received one of four diets, two containing $70 \%$ roughage and two containing $30 \%$ roughage, with and without the inclusion of glycerin (Table 1).

Table 1. Ingredient percentage and nutritional composition of total rations (\%DM).

\begin{tabular}{lcccc}
\hline \multirow{2}{*}{ Ingredient } & \multicolumn{3}{c}{ Diet $^{1}$} \\
\cline { 2 - 5 } & $70 \mathrm{RG}$ & $70 \mathrm{R}$ & $30 \mathrm{RG}$ & $30 \mathrm{R}$ \\
\hline Corn silage & 70.0 & 70.0 & 30.0 & 30.0 \\
Sunflower meal & 5.5 & 5.5 & 5.5 & 5.5 \\
Soybean hulls & 2.75 & 2.75 & 21.7 & 21.3 \\
Corn grain & - & 20.85 & 21 & 42 \\
Urea & 1.0 & 0.35 & 0.75 & 0.15 \\
Crude glycerin & 20.0 & - & 20.0 & - \\
Calcitic limestone & 0.4 & 0.3 & 0.45 & 0.45 \\
Mineral mix & 0.35 & 0.25 & 0.6 & 0.6 \\
& & & & continue
\end{tabular}


continuation

\section{Nutritional Composition}

\begin{tabular}{|c|c|c|c|c|}
\hline Crude protein & 12.0 & 12.7 & 12.0 & 12.3 \\
\hline Neutral detergent fiber & 31.2 & 46.9 & 43.9 & 47.0 \\
\hline Acid detergent fiber & 19.8 & 27.4 & 23.2 & 26.2 \\
\hline Starch & 23.0 & 41.6 & 28.9 & 42.3 \\
\hline Ether extract & 1.1 & 3.7 & 1.7 & 4.1 \\
\hline Metabolizable energy $($ Mcal kg-1) & 2.6 & 2.6 & 2.7 & 2.7 \\
\hline
\end{tabular}

Meals were given twice a day at a 12-h interval, and the daily feeding rations were adjusted to $2 \%$ of the body weight. Glycerin was weighed separately and added to the concentrate and silage at the time of feeding.

The in vitro disappearance of DM, crude protein (CP), and neutral detergent fibre (NDF) from the total rations and ration ingredients was assessed using the DAISYII fermenter $\left(\mathrm{ANKOM}^{\circledR}\right)$. Samples were ground to $1.0 \mathrm{~mm}$, weighed $(0.5 \mathrm{~g})$, and placed into F57 filter bags $\left(\mathrm{ANKOM}^{\circledR}\right)$. The bags were incubated in digestion jars containing $1330 \mathrm{~mL}$ of buffer A (containing $10.0 \mathrm{~g} \mathrm{~L}^{-1} \mathrm{KH}_{2} \mathrm{PO}_{4}, 0.5 \mathrm{~g} \mathrm{~L}^{-1}$ $\mathrm{MgSO}_{4} \cdot 7 \mathrm{H}_{2} \mathrm{O}, 0.5 \mathrm{~g} \mathrm{~L}^{-1} \mathrm{NaCl}, 0.1 \mathrm{~g} \mathrm{~L}^{-1} \mathrm{CaCl}_{2} \cdot 2 \mathrm{H}_{2} \mathrm{O}$ and $0.5 \mathrm{~g} \mathrm{~L}^{-1}$ urea), $266 \mathrm{~mL}$ of buffer $\mathrm{B}$ (containing $15.0 \mathrm{~g} \mathrm{~L}^{-1} \mathrm{Na}_{2} \mathrm{CO}_{3}$ and $1.0 \mathrm{~g} \mathrm{~L}^{-1} \mathrm{Na}_{2} \mathrm{~S} \bullet 9 \mathrm{H}_{2} \mathrm{O}$ ), and $400 \mathrm{~mL}$ of rumen fluid. $\mathrm{CO}_{2}$ was added to the jars at the time of incubation to promote anaerobic conditions. Jars were kept in the fermenter under constant rotation for $48 \mathrm{~h}$ at $39^{\circ} \mathrm{C}$.

Samples and residues from the incubation were analysed to determine $\mathrm{DM}$ at $105^{\circ} \mathrm{C}, \mathrm{CP}$ (AOAC, 1995), starch (HENDRIX, 1993), and NDF content (VAN SOEST; WINE, 1967). Nutrient (DM, CP, $\mathrm{NDF}$, and acid detergent fibre; ADF) disappearance was calculated according to the equation Dis $=(\mathrm{MI}$ $-\mathrm{MR}) / \mathrm{MI} \times 100$, where Dis is the disappearance, MI is the mass of nutrient incubated, and MR is the mass of nutrient in the residue.
In vivo digestibility was estimated using the indigestible neutral detergent fibre (INDF) as an internal indicator (CASALI et al., 2008). After the 10-day diet adaptation period, faeces samples were collected every $8 \mathrm{~h}$ for 3 days and composited for later analysis. Samples were pre-dried $\left(55^{\circ} \mathrm{C}\right)$ and ground to $2 \mathrm{~mm}$. Then, samples were weighed (5 g), placed in nylon bags, and incubated in the rumen of each animal for 12 days, after which the bags were washed, dried, and weighed.

NDF analysis was performed using the undegraded residue to determine the INDF. The percentage of INDF in each sample was calculated using the equation: \%iNDF = incubated sample mass $(\mathrm{g}$ of $\mathrm{DM}) \times \% \mathrm{NDF}$ of the residue/mass of the residue ( $\mathrm{g}$ of DM). Digestibility was calculated using the following equations: DMD $(\%)=1$ $(\%$ INDF feed $/ \%$ INDF faeces $) \times 100 ;$ DNutrient $(\%)$ $=1-[(\% \mathrm{INDF}$ feed $/ \% \mathrm{INDF}$ faeces $) \times(\%$ Nutrient in faeces/\%Nutrient in feed) $] \times 100$.

A $4 \times 4$ Latin Square design was used in a $2 \times$ 2 factorial arrangement (two roughage proportions $\times$ glycerin inclusion). Each experimental period consisted of 10 days for diet adaptation and 5 days for sample collection. SAS 9.0 PROC GLM was used for data analysis. 


\section{Results and Discussion}

The inclusion of glycerin and the proportion of roughage did not influence $(\mathrm{P}>0.05)$ nutrient disappearance of ration ingredients; therefore, only mean values and standard deviations are presented in Table 2. The ingredient with the greatest $(\mathrm{P}<$ 0.05) DM disappearance (DMDis) was corn grain, followed by soybean hulls, sunflower meal, and corn silage. Sunflower meal and corn silage did not differ from each other $(P>0.05)$. Sunflower meal showed higher $(\mathrm{P}<0.05) \mathrm{CP}$ disappearance $(\mathrm{CPDis})$ than the other ingredients, which showed no difference between each other $(\mathrm{P}>0.05)$. NDF digestibility (NDFD) of soybean hulls was higher $(\mathrm{P}<0.05)$ than that of other ingredients. Corn silage had the second highest $(\mathrm{P}<0.05)$ NDFD, followed by corn grain and sunflower meal, which did not differ $(\mathrm{P}>0.05)$ from each other (Table 2). These results clearly show the superior quality of soybean hulls and corn silage in comparison to the other ingredients.

Table 2. In vitro dry matter (DMDis), crude protein (CPDis), and neutral detergent fiber (NDFDis) disappearance of each ration ingredient.

\begin{tabular}{lcccccc}
\hline \multirow{2}{*}{ Variable, $\%$} & \multicolumn{5}{c}{ Ingredient } & \multirow{2}{*}{ SE } \\
\cline { 2 - 5 } & Corn grain & Soybean hulls & Sunflower meal & Corn silage & & \\
\hline DMDis & $81.4 \pm 2.7 \mathrm{a}$ & $71.6 \pm 4.7 \mathrm{~b}$ & $54.1 \pm 2.1 \mathrm{c}$ & $56.7 \pm 3.3 \mathrm{c}$ & $* * *$ & 3.0 \\
CPDis & $73.4 \pm 10.9 \mathrm{~b}$ & $67.8 \pm 4.7 \mathrm{~b}$ & $88.7 \pm 2.0 \mathrm{~b}$ & $72.6 \pm 11.5 \mathrm{~b}$ & $* * *$ & 9.4 \\
NDFDis & $33.9 \pm 8.4 \mathrm{c}$ & $73.1 \pm 4.9 \mathrm{a}$ & $35.6 \pm 5.2 \mathrm{c}$ & $61.9 \pm 8.0 \mathrm{~b}$ & $* * *$ & 5.7 \\
\hline
\end{tabular}

Means followed by the same letter in a line do not differ significantly according to Tukey's test $(\mathrm{P}>0.05)$; $\mathrm{P}$, probability; SE, standard error.

The results of nutrient disappearance of ration ingredients, after analysis of variance, revealed interaction $(\mathrm{P}<0.05)$ solely between the main factors; thus, only these results are presented. Regardless of the inclusion of glycerin, reduction in the proportion of roughage in the diet caused an increase $(\mathrm{P}<0.05)$ in DMDis and in NDF disappearance (NDFDis) of the total rations. Glycerin inclusion provided greater nutrient disappearance in the diet containing
$30 \%$ roughage. In the case of the diets containing $70 \%$ roughage, glycerin supplementation increased $(\mathrm{P}<0.05) \mathrm{CPDis}$ and NDFDis without affecting ( $\mathrm{P}$ $>0.05)$ DMDis and ADF disappearance (ADFDis) (Table 3). The associative effect of the ingredients in the diets may alter their utilisation, independent of diet composition and the proportion of concentrate (MCDONALD et al., 1993).

Table 3. In vitro dry matter (DMDis), crude protein (CPDis), neutral detergent fiber (NDFDis), and acid detergent fiber (ADFDis) disappearance of total rations.

\begin{tabular}{|c|c|c|c|c|c|c|c|c|}
\hline \multirow{2}{*}{ Variable, \% } & \multirow{2}{*}{ Glycerin } & \multicolumn{2}{|c|}{ \%Roughage } & \multirow{2}{*}{ Mean } & \multirow{2}{*}{ SE } & \multicolumn{3}{|c|}{ Effect } \\
\hline & & $70 \mathrm{R}$ & $30 \mathrm{R}$ & & & $\mathrm{R}$ & $\mathrm{G}$ & $\mathrm{R} \times \mathrm{G}$ \\
\hline \multirow{4}{*}{ DMDis } & Included & $65.8 \pm 3.6 \mathrm{Ab}$ & $75.0 \pm 3.2 \mathrm{Aa}$ & $70.4 \pm 5.7 \mathrm{~A}$ & & & & \\
\hline & Not included & $63.5 \pm 4.3 \mathrm{Ab}$ & $68.6 \pm 4.5 \mathrm{Ba}$ & $66.0 \pm 5.0 \mathrm{~B}$ & 3.2 & $* * *$ & $* * *$ & $*$ \\
\hline & Mean & $64.6 \pm 4.0 \mathrm{~b}$ & $71.8 \pm 5.0 \mathrm{a}$ & & & & & \\
\hline & Included & $76.4 \pm 2.4 \mathrm{Ab}$ & $82.7 \pm 2.1 \mathrm{Aa}$ & $79.6 \pm 3.9 \mathrm{~A}$ & & & & \\
\hline
\end{tabular}


continuation

\begin{tabular}{|c|c|c|c|c|c|c|c|c|}
\hline \multirow[t]{3}{*}{ CPDis } & Not included & $72.9 \pm 3.3 \mathrm{Ba}$ & $73.5 \pm 4.1 \mathrm{Ba}$ & $73.2 \pm 3.7 \mathrm{~B}$ & 2.7 & $* * *$ & $* * *$ & $* * *$ \\
\hline & Mean & $74.7 \pm 3.4 \mathrm{~b}$ & $78.1 \pm 5.6 \mathrm{a}$ & & & & & \\
\hline & Included & $43.5 \pm 7.1 \mathrm{Ab}$ & $58.2 \pm 6.6 \mathrm{Aa}$ & $50.9 \pm 10.1 \mathrm{~A}$ & & & & \\
\hline \multirow[t]{3}{*}{ NDFDis } & Not included & $39.4 \pm 5.7 \mathrm{Bb}$ & $49.6 \pm 8.7 \mathrm{Ba}$ & $44.5 \pm 8.9 \mathrm{~B}$ & 5.0 & $* * *$ & $* * *$ & ns \\
\hline & Mean & $41.4 \pm 6.7 \mathrm{~b}$ & $53.9 \pm 8.8 \mathrm{a}$ & & & & & \\
\hline & Included & $32.8 \pm 7.0 \mathrm{Ab}$ & $47.7 \pm 6.2 \mathrm{Aa}$ & $40.3 \pm 9.9 \mathrm{~A}$ & & & & \\
\hline \multirow[t]{2}{*}{ ADFDis } & Not included & $30.2 \pm 4.0 \mathrm{Ab}$ & $40.1 \pm 7.5 \mathrm{Ba}$ & $35.1 \pm 7.8 \mathrm{~B}$ & 5.6 & $* * *$ & $* * *$ & ns \\
\hline & Mean & $31.5 \pm 5.7 \mathrm{~b}$ & $43.9 \pm 7.8 \mathrm{a}$ & & & & & \\
\hline
\end{tabular}

Within rows, means followed by the same lowercase letter do not differ significantly according to Tukey's test (P $>0.05)$; within columns, means followed by the same uppercase letter do not differ significantly according to Tukey's test (P $>0.05)$; SE, standard error; $\mathrm{R}$, roughage; $\mathrm{G}$, glycerin; $\mathrm{RxG}$, interaction.

In the literature, there are conflicting results for DMDis from glycerin-containing feeds. AvilaStagno et al. (2011) reported a linear increase in DMDis when barley grain was substituted by glycerol at increasing concentrations ( 7 to 14 to $21 \%$ of total DM). Corroborating the results of the present study, Hampy et al. (2007) reported a linear increase in DM digestibility (DMD) of forage by increasing levels of glycerol from 5 to 10 to $20 \%$ of total DM. However, Ramos and Kerley (2012) demonstrated a linear reduction in DMD of total rations with a high proportion of roughage.

In this study, 20\% crude glycerin was used which contains $83 \%$ glycerol, corresponding to an inclusion of glycerol at approximately $16 \%$ of total DM. Glycerin did not affect the disappearance of the nutritional components of the total ration, especially that of fibre. This finding is in contrast to the results of a study by Roger et al. (1992), in which the inclusion of $5 \%$ glycerol drastically reduced growth and cellulolytic activity of two bacterial species. In the present study, glycerol at $16 \%$ of total DM had positive effects on the disappearance of total ration fibre, contrary to a report that 7.2 or $10.8 \%$ of glycerol reduced fibre digestibility (ABO EL-NOR et al., 2010). The benefits of glycerin supplementation may be related to its high digestibility; $80 \%$ digestibility was observed after $24 \mathrm{~h}$ of in vitro incubation (TRABUE et al., 2007).

No interaction $(\mathrm{P}>0.05)$ between factors was observed for DMD, CP digestibility (CPD), and starch digestibility (STD); therefore, only the main factors are shown in Table 4. Inclusion of glycerin increased $(\mathrm{P}<0.05) \mathrm{DMD}$, but caused a reduction $(\mathrm{P}<0.05)$ in $\mathrm{CPD}$ and STD. According to Wang et al. (2009), the inclusion of 1.1 or $2.2 \%$ of glycerol in diets of cattle promoted an increase in nutrient digestibility, whereas glycerol at $3.3 \%$ of DM resulted in a reduction. According to Farias et al. (2012), the inclusion of approximately 3,6 , or $9 \%$ of glycerin did not affect nutrient digestibility of diets fed to heifers supplemented on pasture. In a study by Borges et al. (2013), no changes in nutrient digestibility were observed with the inclusion of 5,10 , or $15 \%$ of crude glycerin in the diet of meat goats fed $45 \%$ of Tifton 85 bermudagrass. 
Table 4. Apparent digestibility of dry matter (DMD), crude protein (CPD), and starch (STD) of the diets.

\begin{tabular}{|c|c|c|c|c|c|c|c|c|}
\hline \multirow{2}{*}{ Variable, \% } & \multicolumn{2}{|c|}{ \%Roughage } & \multicolumn{2}{|c|}{ Glycerin } & \multirow[t]{2}{*}{$\mathrm{SE}$} & \multicolumn{3}{|c|}{ Effect } \\
\hline & $70 \mathrm{R}$ & $30 \mathrm{R}$ & Included & Not included & & $\mathrm{R}$ & $\mathrm{G}$ & $\mathrm{R} \times \mathrm{G}$ \\
\hline DMD & $64.7 \pm 5.3$ & $67.4 \pm 7.3$ & $70.3 \pm 4.9$ & $61.8 \pm 4.8$ & 2.82 & $* *$ & $* * *$ & ns \\
\hline CPD & $33.2 \pm 9.2$ & $37.3 \pm 7.5$ & $32.2 \pm 6.7$ & $38.3 \pm 9.2$ & 6.5 & $*$ & $* * *$ & $\mathrm{~ns}$ \\
\hline STD & $75.1 \pm 14.9$ & $81.1 \pm 4.6$ & $74.4 \pm 3.9$ & $81.9 \pm 17.3$ & 12.2 & ns & $*$ & ns \\
\hline
\end{tabular}

SE, standard error; R, roughage; G, glycerin; RxG, interaction.

The diet containing 30\% roughage led to higher $(\mathrm{P}<0.05)$ DMD and CPD but did not differ $(\mathrm{P}>$ $0.05)$ in STD in comparison with the diet containing $70 \%$ roughage (Table 4 ). The higher utilisation of the $30 \%$ roughage diet may be due to differences in the DMDis of the ingredients, as corn silage had lower utilisation than soybean hulls and corn grain (Table 2). This study corroborates published data, showing that a reduction in dietary roughage promotes an increase in the digestibility of dry matter and crude protein (VERÁS et al., 2000;
RESENDE et al., 2001; PEREIRA et al., 2007). However, some authors reported an increase in DMD but no increase in CPD (ÍTAVO et al., 2002; SILVA et al., 2005).

Data on the interaction between the main factors of NDFD are presented in Table 5. Glycerin supplementation improved $(\mathrm{P}<0.05)$ NDFD of the $70 \%$ roughage diet, whereas for the $30 \%$ roughage diet, it had no effect $(\mathrm{P}<0.05)$. These results suggest that glycerin improves the utilisation of the fibrous fraction of high-roughage diets.

Table 5. Effect of the interaction of roughage and glycerin on neutral detergent fiber digestibility (NDFD) of the diets.

\begin{tabular}{|c|c|c|c|c|c|c|c|c|}
\hline \multirow{2}{*}{ Variable, \% } & \multirow{2}{*}{ Glycerin } & \multicolumn{2}{|c|}{ \%Roughage } & \multirow{2}{*}{ Mean } & \multirow{2}{*}{$\mathrm{SE}$} & \multicolumn{3}{|c|}{ Effect } \\
\hline & & $70 \mathrm{R}$ & $30 \mathrm{R}$ & & & $\mathrm{R}$ & G & $\mathrm{R} \times \mathrm{G}$ \\
\hline \multirow{3}{*}{ NDFD } & Included & $73.1 \mathrm{Aa}$ & $57.4 \mathrm{Ab}$ & $65.2 \mathrm{~A}$ & & & & \\
\hline & Not included & $56.9 \mathrm{Ba}$ & $56.3 \mathrm{Aa}$ & $56.6 \mathrm{~B}$ & 8.9 & $* *$ & $* *$ & $* *$ \\
\hline & Mean & $65.0 \mathrm{a}$ & $56.9 \mathrm{~b}$ & & & & & \\
\hline
\end{tabular}

Within rows, means followed by the same lowercase letter do not differ significantly according to Tukey's test $(\mathrm{P}>0.05)$; within columns, means followed by the same uppercase letter do not differ significantly according to Tukey's test (P >0.05); SE, standard error; R, roughage; $\mathrm{G}$, glycerin; $\mathrm{RxG}$, interaction.

A reduction in NDFD was observed when the proportion of roughage in diets containing glycerin was reduced from 70 to $30 \%$, but this effect was not observed for diets with no glycerin supplementation $(\mathrm{P}>0.05$; Table 5). This effect may be due to the absence of corn in the diet containing glycerin and $70 \%$ roughage, as the $\mathrm{pH}$ of the ruminal environment is probably higher and thus favours the performance of cellulolytic microorganisms responsible for cellulose degradation (DIJKSTRA et al., 2012).

\section{Conclusions}

Inclusion of glycerin at $20 \%$ of the total DM increased the utilisation of dietary DM without affecting the utilisation of the fibrous fraction of the diet. Glycerin supplementation in diets containing $70 \%$ roughage improves neutral detergent fibre digestibility. 


\section{Acknowledgements}

We thank CNPq/PIBIC for the scientific initiation scholarship and Caramuru Alimentos S/A for supplying some of the ingredients used in this study.

\section{Ethics and Biosafety Committee}

This work was conducted in accordance with the guidelines of the National Council for the Control of Animal Experimentation (CONCEA) and approved by the Ethics Committee on Animal Use (CEUA) of the São Paulo State University (protocol no. 028066/12).

\section{References}

ABO EL-NOR, S.; ABUGHAZALEH, A. A.; POTU, R. B.; HASTINGS, D.; KHATTAB, M. S. A. Effects of differing levels of glycerol on rumen fermentation and bacteria. Animal Feed Science and Technology, Amsterdam, v. 162, n. 3-4, p. 99-105, 2010.

ASSOCIATION OF OFFICIAL ANALYTICAL CHEMIST - AOAC. Official methods of analysis. 6. ed. Washington: AOAC, 1995. $2000 \mathrm{p}$.

AVILA-STAGNO, J.; CHAVES, A. V.; HE, M. L.; HARSTAD, O. M.; BEAUCHEMIN, K. A.; McGINN, S. M.; McALLISTER, T. A. Effects of increasing concentrations of glycerol in concentrate diets on nutrient digestibility, methane emissions, growth, fatty acid profiles, and carcass traits of lambs. Journal of Animal Science, Champaign, v. 91, n. 2, p. 829-837, 2013.

AVILA-STAGNO, J.; CHAVES, A. V.; HERNANDEZCALVA, M.; BEACHEMIN, K.; McGINN, S. M.; WANG, Y.; HARSTAD, O. M.; McALLISTER, T. A. Effects of replacing barley grain in feedlot diets with increasing levels of glycerol on in vitro fermentation and methane production. Animal Feed Science and Technology, Amsterdam, v. 166-167, n. 23, p. 265-268, 2011.

BORGES, G. D. S.; MACEDO, V. P.; MAEDA, E. M.; SILVEIRA, A. L. F.; CASTRO, J. M. Digestibilidade de dietas contendo níveis de glicerina bruta em substituição ao milho fornecidas a caprinos de corte. Synergismus Scyentifica UTFPR, Pato Branco, v. 8, n. 2, p. 1-3, 2013.

CASALI, A. O.; DETMANN, E.; VALADARES FILHO, S. C.; PEREIRA, J. C.; HENRIQUES, L. T.; FREITA, S.
G.; PAULINO, M. F. Influência do tempo de incubação e do tamanho de partículas sobre os teores de compostos indigestíveis em alimentos e fezes bovinas obtidos por procedimentos in situ. Revista Brasileira de Zootecnia, Viçosa, MG, v. 37, n. 2, p. 335-342, 2008.

DIJKSTRA, J.; ELLIS, J. L.; KEBREAB, E.; STRATHE, A. B.; LÓPEZ, S.; FRANCE, J.; BANNINK, A. Ruminal $\mathrm{pH}$ regulation and nutritional consequences of low $\mathrm{pH}$. Animal Feed Science and Technology, Amsterdam, v. 172, n. 1-2, p. 22-33, 2012.

DONKIN, S. S. Glycerol from biodiesel production: the new corn for dairy cattle. Revista Brasileira de Zootecnia, Viçosa, MG, v. 37, p. 280-286, 2008. Número Especial.

FARIAS, M. S.; PRADO, I. N.; VALERO, M. V.; ZAWADZKI, F.; SILVA, R. R.; EIRAS, C. E.; RIVAROLI, D. C.; LIMA, B. S. Níveis de glicerina para novilhas suplementadas em pastagens: desempenho, ingestão, eficiência alimentar e digestibilidade. Semina: Ciências Agrárias, Londrina, v. 33, n. 3, p. 1177-188, 2012.

HAMPY, K. R.; KELLOGG, D. W.; COFFEY, K. P.; ANSCHUTZ, K. In vitro DM digestibility of crabgrass, bermudagrass, and wheat forages supplemented with four levels of glycerol. Arkansas Agricultural Experiment Station Research Series, Fayettteville, v. 553, n. 1, p. 6566, 2007.

HENDRIX, D. L. Rapid extraction and analysis of nonstructural carbohydrates in plant tissues. Crop Science, Madison, v. 33, n. 6, p. 1306-1311, 1993.

ÍTAVO, L. C. V.; VALADARES FILHO, S. C.; SILVA, F. F.; VALADARES, R. F. D.; LEÃO, M. I.; CECON, P. R.; ÍTAVO, C. C. B. F.; MORAES, E. H. B. K.; PAULINO, P. V. R. Consumo e digestibilidade aparentes totais e parciais de nutrientes em novilhos alimentados com dietas contendo vários níveis de concentrado. Revista Brasileira de Zootecnia, Viçosa, MG, v. 31, n. 3, p. 1543-1552, 2002.

McDONALD, P.; EDWARDS, R.; GREENHALGH, J. F. D. Nutricion animal. 4. ed. Zaragoza: Acribia, 1993. $571 \mathrm{p}$.

PEREIRA, D. H.; PEREIRA, O. G.; SILVA, B. C.; LEÃO, M. I.; VALADARES FILHO, S. C.; CHIZZOTTI, F. H. M.; GARCIA, R. Intake and total and partial digestibility of nutrients, ruminal $\mathrm{pH}$ and ammonia concentration and microbial efficiency in beef cattle fed with diets containing sorghum (Sorghum bicolor (L.) Moench) silage and concentrate in different ratios. Livestock Science, Amsterdam, v. 107, n. 1, p. 53-61, 2007.

RAMOS, M. H.; KERLEY, M. S. Effect of dietary crude glycerol level on ruminal fermentation in continuous 
culture and growth performance of beef calves. Journal of Animal Science, Champaign, v. 90, n. 3, p. 892-899, 2012.

RESENDE, F. D.; QUEIROZ, A. C.; OLIVEIRA, J. V.; PEREIRA, J. C.; MÂNCIO, A. B. Bovinos mestiços confinados alimentados com diferentes proporções de volumoso: concentrado. 1. Digestibilidade aparente dos nutrientes, ganho de peso e conversão alimentar. Revista Brasileira de Zootecnia, Viçosa, MG, v. 30, n. 1, p. 264272, 2001.

ROGER, V.; FONTY, G.; ANDRE, C.; GOUET, P. Effects of glycerol on the growth, adhesion and cellulolytic activity of rumen cellulolytic bacteria and anaerobic fungi. Current Microbiology, New York, v. 25, n. 4, p. 197-201, 1992.

SILVA, B. C.; PEREIRA, O. G.; PEREIRA, D. H.; GARCIA, R.; VALADARES FILHO, S. C.; CHIZZOTTI, F. H. M. Consumo e digestibilidade aparente total dos nutrientes e ganho de peso de bovinos de corte alimentados com silagem de Brachiaria brizantha e concentrado em diferentes proporções. Revista Brasileira de Zootecnia, Viçosa, MG, v. 34, n. 3, p. 1060-1069, 2005.
TRABUE, S.; SCOGGIN, K.; TJANDRAKUSUMA, M. A.; RASMUSSEN, M. A.; REILLY, P. J. Ruminal fermentation of propylene glycol and glycerol. Journal of Agricultural and Food Chemistry, Washington, v. 55, n. 17, p. 7043-7051, 2007.

VAN SOEST, P. J.; WINE, R. H. Use of detergents in analysis of fibrous feeds. IV. Determinations of plant cell-wall constituents. Journal of Association of Official Analytical Chemists, Arlington, v. 50, n. 1, p. 50-55, 1967.

VÉRAS, A. S. C.; VALADARES FILHO, S. C.; SILVA, J. F. C.; PAULINO, M. F.; CECON, P. R.; VALADARES, R. F. D.; FERREIRA, M. A.; CABRAL, L. S. Consumo de digestibilidade aparente em bovinos Nellore, não castrados, alimentados com rações com diferentes níveis de concentrado. Revista Brasileira de Zootecnia, Viçosa, MG, v. 29, n. 6, p. 2367-2378, 2000.

WANG, C.; LIU, Q.; HUO, W. J.; YANG, W. Z.; DONG, K. H.; HUANG, Y. X.; GUO, G. Effects of glycerol on rumen fermentation, urinary excretion of purine derivatives and feed digestibility in steers. Livestock Science, Amsterdam, v. 121, n. 1, p. 15-20, 2009. 